\title{
12 \\ Paul Dibb and the Asian Balance of Power
}

\author{
Brendan Taylor
}

For a medium-sized country, Australia has enjoyed an uncanny prominence when it comes to scholarship addressing the Asian balance of power. Such intellectual giants in the fields of international relations and strategic studies as Coral Bell, Hedley Bull and Hugh White have each contributed seminal works on this subject. Yet it would be by no means hyperbolic to describe Paul Dibb as primus inter pares, or 'first among equals', when referring to his scholarship in this particular area. Reviewing that scholarship, this chapter begins by providing a brief summary of work on the Asian balance of power and seeks to account for the prominence of Australian scholars within it. The chapter then analyses Paul Dibb's contribution to this scholarship, particularly his Adelphi Paper from the mid-1990s, which this chapter judges to be the classic academic treatment of the Asian balance. Finally, during an era when balance-of-power politics appears to be truly coming into fashion in Asia, the chapter concludes by asking what contemporary scholars and analysts can usefully take and apply from the Dibb approach. 


\section{Australians and the Asian Balance}

The balance of power is one of the oldest ideas in the theory and practice of international politics. Writing over 2,000 years ago, for instance, Thucydides attributed a fundamental shift in the balance of power between Ancient Greece's two leading city states - Athens and Sparta - as a precipitating cause of the Peloponnesian War. ${ }^{1}$ Less often acknowledged is that power-balancing behaviour was also a central feature of Ancient China during the so-called Spring, Autumn and Warring States periods from 770-221 BC. ${ }^{2}$ Balance-ofpower theory was also evident in the work of political scientists and historians who studied relations between the Italian city states during the fifteenth and sixteenth centuries. ${ }^{3}$

The application of the balance of power in a specifically 'Asian' context has a similarly distinguished and enduring lineage. Writing over 100 years ago, for instance, the renowned American geostrategist Alfred Thayer Mahan broke with tradition to argue that the security of an emergent United States was intimately tied to the Asian balance of power as well as to that of Europe. ${ }^{4}$ Writing more than half a century later, the father of realism, Hans Morgenthau, also identified the importance of the Asian balance to the United States, highlighting the critical importance to America of preventing 'any one European or Asian power from gaining control of the power potential of China, acquiring a monopoly for the exploitation of China'. ${ }^{5}$

Amongst Australian scholars, the work of Bell stands as a pioneering contribution to scholarship on the Asian balance. Writing also during the 1960s, Bell published one of the earliest papers in the then Institute for Strategic Studies' Adelphi series, in which she considered the

1 Robert B. Strassler (ed.), The Landmark Thucydides: A Comprehensive Guide to the Peloponnesian War (New York: Free Press, 2008), p. 16.

2 Victoria Tin-bor Hui, War and State Formation in Ancient China and Early Modern Europe (New York: Cambridge University Press, 2005).

3 Richard Little, The Balance of Power in International Relations: Metaphors, Myths and Models (Cambridge University Press, 2007), p. 4.

4 Alfred Thayer Mahan, The Problem of Asia: Its Effect upon International Politics (New Brunswick: Transaction Publishers, 2003).

5 Hans J. Morgenthau, Truth and Power: Essays of a Decade, 1960-1970 (London: Pall Mall Press, 1970), p. 391. 
applicability of the balance-of-power concept to an Asian context. ${ }^{6}$ Writing in the prestigious American policy journal Foreign Affairs during the early 1970s, Bell's Australian contemporary Hedley Bull speculated about the emergence of a new, four-sided 'complex' balance of power in the Asia-Pacific that included the United States, the Soviet Union, China and Japan. ${ }^{7}$ In recent years, Hugh White has picked up Bull's conceptual baton, writing of a slightly different four-sided balance comprising the United States, China, Japan and India. White's proposal that this balance can best be managed through a concert of power-type arrangement similar to that which existed in Europe throughout much of the nineteenth century has attracted widespread attention and an equal measure of criticism, including from the man whose work forms the focus of this chapter. ${ }^{8}$

What explains the prevalence of Australian scholars in writings on the Asian balance of power?

First and foremost, Australia's strategic geography and, in particular, this country's proximity to Asia have unquestionably played a role. As Bell observes in the opening stanzas of her Adelphi Paper:

perhaps there is a certain appropriateness to an Australian examination of this question since Australians are the only group of Westerners who must remain fully and inescapably vulnerable to the diplomatic stresses arising in Asia, on whose periphery they live or die. ${ }^{9}$

At the same time, however, Australia's geographic remoteness and relative distant from Asia's major power machinations also go some way towards explaining the prominence of Australian scholarship in this area. Precisely for reasons of distance, a case can be made that Australians can look at the Asian balance more objectively and systematically than, for instance, scholars and practitioners from those countries that are geographically closer and whose very national existence is potentially contingent upon shifts in that balance. Japan, for instance, has historically also been acutely attentive to changes

6 Coral Bell, The Asian Balance of Power: A Comparison with European Precedents, Adelphi Paper No. 44 (London: International Institute for Strategic Studies, Feb. 1968).

7 Hedley Bull, 'The New Balance of Power in Asia and the Pacific', Foreign Affairs, Vol. 49, No. 4 (Jul. 1971), pp. 669-81.

8 Hugh White, The China Choice: Why America Should Share Power (Collingwood: Black Inc, 2012).

9 Bell, The Asian Balance of Power (1968), p. 1. 
in the Asian balance. In Japan's case, however, the balance has been viewed more subjectively and in terms of what balance-of-power policy should be adopted either in anticipation or in response to those shifts. ${ }^{10}$

Second, links to the 'home country' Great Britain also have played a hand in the prominence of Australian scholarship addressing the Asian balance. While, as noted previously, balance-of-power thinking was in evident in ancient times, the concept had its formal beginnings in fifteenth-century Europe and really took root there from the late seventeenth century onwards. ${ }^{11}$ The British embraced the concept with particular enthusiasm for, as Michael Sheehan notes:

Britain was not in a position to play a significant role in determining the outcome of European politics except in conditions of equilibrium and ... it was therefore of paramount importance that she should strive always to maintain a balance of power on the continent. ${ }^{12}$

It is interesting to note here that each of the Australian scholars most prominently associated with the Asian balance of power have strong British links. Dibb, of course, was born in England and spent the first two decades of his life there. Bell and Bull both studied and worked in England for lengthy periods. White studied there also. Moreover, reflecting upon his time as an official in the Australian Department of Defence, White explicitly recalls the direct influence of British thinking:

During the early 1990s some of us working in Defence began exploring this problem of defining Australia's wider strategic interests in the post-Cold War world. Our attention was caught by Lord Palmerston's famous line about 'Britain having no permanent friends and no permanent enemies, only permanent interests'. We started to look at how Britain defined these permanent interests, and what we might learn from them ... the British experience seemed worth examining, not because of historical or sentimental connections with the UK, but because of certain geostrategic similarities. Like Australia, Britain is an island lying offshore a continent of major powers. ${ }^{13}$

10 For further reading see Kenneth B. Pyle, The Resurgence of Japanese Power and Purpose (New York: Public Affairs, 2007).

11 Little, The Balance of Power in International Relations (2007), p. 4.

12 Michael Sheehan, The Balance of Power: History and Theory (Abingdon: Routledge, 1996), p. 51.

13 Hugh White, 'Strategic Interests in Australian Defence Policy: Some Historical and Methodological Reflections', Security Challenges, Vol. 4, No. 2 (Winter 2008), p. 69. 
Third, the international prominence of Australian scholarship on the Asian balance is consistent with what Michael Wesley has termed the 'rich tradition of Australian realism' ${ }^{14}$ Wesley downplays the extent to which Australian international relations scholarship is derivative of that developed either in Britain or North America. Instead, he contends that, since the 1920s, a distinctly Australian strain of realism has developed and evolved in the antipodes. It is a form of realism that is highly pragmatic, a-theoretical in nature and influenced by practitioner-academics. That said, while balance-of-power theory may thus not appear explicitly as a central feature in Australian international relations scholarship, Wesley goes on to identify the analysis of 'power disparities' as one of the preoccupations of this body of work. He also points to an obsession with 'understanding the strategic mind of great powers' and a desire to prevent 'the domination of global decision-making by a great power cartel'. As the next section of this chapter goes on to discuss, each of these features is certainly evident in Dibb's work on the Asian balance.

\section{Dibb and the Asian Balance}

Dibb's 1995 Adelphi Paper, Towards a New Balance of Power in Asia, sits comfortably alongside the seminal contributions of Mahan, Morgenthau, Bell, Bull and White, amongst others. Indeed, a strong case can be made that Dibb's Adelphi should be regarded as the classic treatment on the subject. It is certainly a widely cited work and one, as this chapter goes on to discuss, which exhibits a remarkable degree of prescience when seen in the context of the shifting power dynamics that are evident in Asia today.

In characteristic style, Dibb begins his classic Adelphi by immediately clarifying how he understands and applies the balance of power concept, thus dealing with the definitional debates that have weighed heavily upon other studies employing this term. While acknowledging the existence of those debates, with reference to his background as a practitioner, Dibb makes the observation that '[i]n the author's experience, the concept of the balance of power is much less contested among foreign policy and defence practitioners than among academics

14 Michael Wesley, 'The Rich Tradition of Australian Realism', Australian Journal of Politics and History, Vol. 55, No. 3 (2009), pp. 324-34. 
and intellectuals'. ${ }^{15}$ His definition 'assumes that nation-states will ensure that no one power is in a position to determine the fate of others' and he sees the balance of power as involving 'a rules-based system that limits both the ability of states to dominate each other and the scope of conflict'. ${ }^{16}$ To borrow from Inis Claude's helpful taxonomy, Dibb thus regards the balance of power as a system rather than as a situation or a policy. ${ }^{17}$

Unlike Bull or White, the balance that Dibb saw emerging in Asia was a pentagonal one consisting of China, Japan, India, Russia and the United States. Dibb described this balance as 'new' to the extent that such a balance had not previously extended right across the entire Asian region. He saw this development of a new region-wide system of order as a potentially dangerous one, particularly given the lack of experience that any of the key players had had with the practice of balance-of-power politics. At best, Dibb observed, only local power balances were a feature of the international relations of Asia prior to this point. ${ }^{18}$ At worst, he drew on the work of Henry Kissinger in this area (a consistent tendency in Dibb's work, as discussed below) to point out that the United States had never previously participated in a balance-of-power system. ${ }^{19}$ Dibb pointed out that one possible exception to the Kissinger thesis might be America's experiences with Japan, China and Britain in East Asia during the 1920s and 1930s, which ended badly of course. ${ }^{20}$

While pointing to the emergence of a new balance of power system in Asia, Dibb was quick to observe that this arrangement would not be akin to a concert of power. This argument has again remained a consistent feature of his work during the period since and has been one of his key points of contention with White in their respective

15 Paul Dibb, Towards a New Balance of Power in Asia, Adelphi Paper No. 295 (London: International Institute for Strategic Studies, 1995), p. 75.

16 Dibb, Towards a New Balance of Power in Asia (1995), p.6.

17 In an attempt to streamline the innumerable applications of the balance of power terminology, Claude sought to categorise these into three broad groups. The balance as a 'situation' was a largely descriptive application, referring simply to the distribution of military power. The balance as a 'policy' referred to the approaches which individual states pursue when taking that distribution into account. The balance of power as a 'system' refers more broadly to the operation of international relations at a more systemic level, including the interactions between the states within that system. See Inis Claude, Power and International Relations (New York: Random House, 1962).

18 Dibb, Towards a New Balance of Power in Asia (1995), p. 10.

19 Dibb, Towards a New Balance of Power in Asia (1995), p. 38.

20 Dibb, Towards a New Balance of Power in Asia (1995), p. 12. 
analyses of the contemporary Asian balance. Dibb's primary objection to the notion of a concert, both then and today, is that it would lead to the marginalisation of the small and middle powers in the system, including Australia. In a more recent critique of White's work, for instance, Dibb recalls that 'middle powers such as Poland either disappeared or were carved up' in the nineteenth-century concert of Europe. Dibb also makes the observation that the highly diverse and variegated Asian region of today lacks the common culture which facilitated the functioning of that concert. ${ }^{21}$

In his Adelphi, Dibb also makes the observation that the evolution of the Asian balance will occur gradually, perhaps even glacially. In his terms 'the redistribution of power between Asia and the rest of the world, as well as within Asia, will not be a sudden or catastrophic event. Change in the international status of nations rarely occurs quickly, except in the event of war.'22 Again, this judgement is in keeping with Dibb's more recent work, especially that dealing with shifting power relativities between the United States and China. In a widely cited article co-authored with John Lee and entitled 'Why China Will Not Become the Dominant Power in Asia', Dibb argues that the US-China military balance still significantly favours America. He estimates that China is approximately 20 years behind the United States in high technology weaponry, pointing out also that the People's Liberation Army (PLA) is a force without any modern combat experience, including experience in the complexities of antisubmarine warfare operations. Even as China plays catch up, Dibb points out that the United States is not standing still militarily even with the financial pressures that it has been experiencing over recent years - and that it continues to invest in technological 'game changers' that could actually shift the US-China military balance even further in America's favour. ${ }^{23}$

Consistent with this set of observations regarding the Sino-American military balance, while Dibb takes an explicitly systemic, state-centred approach in the Adelphi, he is also highly attuned to the importance of domestic dynamics and their capacity to shape inter-state power dynamics. In his terms, 'it would be a mistake to be complacent about

21 Paul Dibb, 'Why I Disagree with Hugh White on China's Rise', Australian, 13 Aug. 2012.

22 Dibb, Towards a New Balance of Power in Asia (1995), p. 21.

23 Paul Dibb \& John Lee, 'Why China Will Not Become the Dominant Power in Asia', Security Challenges, Vol. 10, No. 3 (2014), pp. 15-19. 
the underlying social stability of significant actors in Asia'.$^{24}$ In this respect, he would more accurately be labelled as a 'classical realist' rather than one of the 'neo-realist' variety, given the priority which the latter assigns to systemic and structural dynamics, virtually to the exclusion of domestic considerations. ${ }^{25}$ This 'classical' approach has been a feature of Dibb's work throughout his career, as exemplified by his pathbreaking study The Incomplete Superpower, which rather presciently highlighted the domestic weaknesses and fragilities of the Soviet Union as Mikhail Gorbachev came to power. ${ }^{26}$

Dibb never claims to have predicted the demise of the Soviet Union, which came only a few years following the publication of The Incomplete Superpower, but he certainly came closer than most to doing so. This uncanny prescience is also a feature of his work on the Asian balance. Writing 20 years ago, for instance, he observed that ' $[\mathrm{n}] \mathrm{o}$ contemporary issue is more important than the rise of China' ${ }^{27}$ While that may seem a statement of the obvious today, it was much less so in that earlier period when just as many scholars were predicting the collapse or disintegration of China and where others were still talking up the rise of Japan. ${ }^{28}$ On Japan, he predicted 'the emergence of a different sort of Japan', a country that would become 'more outward looking and assertive' ${ }^{29} \mathrm{He}$ suggested that India had 'greater potential as a power of influence than its indicators would suggest', that 'it could emerge as a useful player in a multipolar Asian balance' and that it 'could attract American interest as a counterbalance to China' ${ }^{30}$ On Russia, he warned of the emergence of authoritarianism and a Moscow bent upon (re)establishing 'a powerful, nationalist Great Russian state that would reclaim its "rightful" role in the world'. ${ }^{31}$ Finally, he envisaged a United States that would remain the single most important player in the new Asian balance of power, but that would create anxieties amongst its regional friends and allies as a superpower

24 Dibb, Towards a New Balance of Power in Asia (1995), p. 17.

25 See, for example, John J. Mearsheimer, The Tragedy of Great Power Politics (New York: Norton, 2001).

26 Paul Dibb, The Soviet Union: The Incomplete Superpower (London: International Institute for Strategic Studies and Macmillan, 1986).

27 Dibb, Towards a New Balance of Power in Asia (1995), p. 27.

28 See, for example, Gordon G. Chang, The Coming Collapse of China (New York: Random House, 2001).

29 Dibb, Towards a New Balance of Power in Asia (1995), p. 31.

30 Dibb, Towards a New Balance of Power in Asia (1995), pp. 33-34.

31 Dibb, Towards a New Balance of Power in Asia (1995), p. 36. 
prone to 'domestic preoccupation and which has a foreign policy that merely reacts to events as they unfold'. In his view, 'the US will not be prepared with a grand strategy to advance its interests in Asia's emerging multipolar great-power competition'.$^{32}$

Many analysts and commentators would regard this latter observation as a rather apt description of US grand strategy (or the lack thereof) during the presidency of Barak Obama. ${ }^{33}$ Indeed, there is today remarkably little to quibble with in any of Dibb's assessments of the key players who constitute the new Asian balance.

Dibb concludes the Adelphi by contemplating how Asia's new power balance might function in practice. Again, his analysis of two decades ago has turned out to be remarkably prescient. Although viewing trends towards a deepening in economic cooperation and economic multilateralism as a 'force for peace', ${ }^{34}$ Dibb was sceptical of arguments suggesting that interdependence would serve to dampen the prospects for great power rivalry. And while evidently seeing value in some of the confidence-building activities that were emerging at the time and calling for a deepening of these through, for instance, the introduction of a multilateral agreement on the avoidance of naval incidents which remains a continuing theme in his work today ${ }^{35}$ — Dibb was also dubious regarding the potential for emerging multilateral structures to manage or to militate power balancing behaviour. Again, the region was too diverse for such an outcome. In his terms:

Multilateral institutions are weak in Asia and there is a reluctance to consider formal confidence-building measures and military transparency along the lines of the Organisation for Security and Cooperation (OSCE). These are seen as intrusive, technical armscontrol measures that were appropriate to Europe but which do not reflect either the more complex security situation in Asia or the Asian way of doing business. ${ }^{36}$

Instead, what Dibb saw emerging in Asia was a more fluid and uncertain balance of power - or what he termed an 'unstable equilibrium'. Stability would be delivered through the major players acting to check

32 Dibb, Towards a New Balance of Power in Asia (1995).

33 See, for example, Michael O'Hanlon, 'How to Solve Obama's Grand Strategy Dilemma',

The National Interest, 23 May 2014.

34 Dibb, Towards a New Balance of Power in Asia (1995), p. 53.

35 Paul Dibb, 'Treaty May Steer China, Japan to Safer Waters', Australian, 1 Apr. 2013.

36 Dibb, Towards a New Balance of Power in Asia (1995), p. 66. 
the behaviour of one another, to ensure that none emerged as a regional hegemon. But, unlike in a concert-type arrangement, behaviour would be more competitive, self-serving and characterised by a lack of common interests. In such a setting, the prospect for a serious deterioration in Asia's security environment would, according to Dibb, remain considerable. ${ }^{37}$ And with great prescience, once again, he identified Asia's territorial disputes as a potential trigger for such a deterioration. Of particular note is his observation that 'China's rise to great-power status will be accompanied by coercive levers of power, including the demonstration of a military presence in the South China Sea' ${ }^{\prime 3}$

\section{The Asian Balance: An Idea Whose Time has Come?}

At the time that Dibb published his Adelphi and for much for the period since, it has not been fashionable to discuss Asian security order in terms of balance-of-power politics. Indeed, just as Dibb himself discouraged the direct transplantation of Euro-centric multilateral frameworks into an Asian context, a general consensus seems to have emerged amongst scholars studying the international relations of Asia that the balance-of-power concept does not apply particularly well to this part of the world. In the main, these scholars have highlighted an absence of balancing behaviour during the period since the ending of the Cold War. They have pointed to a lack of evidence suggesting any effort on the part of the United States to 'contain' the rise of China through the establishment of an antiChinese balancing coalition. Equally, they see little evidence of China vigorously balancing against the United States or seeking to replace it as the region's dominant power. ${ }^{39}$

As widely accepted as these arguments have been for some time now, they have become increasingly difficult to sustain in recent years as signs of more overt balancing behaviour emerge in this region.

37 Dibb, Towards a New Balance of Power in Asia (1995), p. 55.

38 Dibb, Towards a New Balance of Power in Asia (1995), p. 40.

39 See, for example, Steve Chan, Looking for Balance: China, the United States, and Power Balancing in East Asia (Stanford University Press, 2012). 
The United States under the Obama administration, for instance, has explicitly labelled its strategy for Asia as one of 'rebalancing', which is widely interpreted as a direct response to growing Chinese power and assertiveness. ${ }^{40} \mathrm{~A}$ range of new initiatives in China, such as President Xi Jinping's 'Asia for Asians' security concept are too increasingly seen as part of a concerted effort on Beijing's part to challenge Asia's US-led security order and to undercut American influence in this part of the world.$^{41}$ Recent changes in Japan's force structure and a further intensification of the US-Japan alliance - as illustrated by the signing of a new 'vision statement' and revised set of 'defence guidelines' charting the future of that relationship during Japanese Prime Minister Shinzo Abe's May 2015 visit to America - have also been characterised as part of a Japanese 'counter-balancing' strategy in the face of China's rise. ${ }^{42}$ Even in South-East Asia, where so-called 'hedging' strategies have long been regarded as the norm, there are clear signs of 'balancing' behaviour emerging, particularly on the part of those countries that feel most threatened by China's growing power and assertiveness, such as the Philippines and Vietnam. ${ }^{43}$

In this era of intensifying Asian balance of power politics, what can scholars and analysts today usefully take from the Dibb approach? First, Dibb's work on the Asian balance highlights the importance of having a clear and coherent conceptual framework. Having such a framework has been one of the defining features across all of Dibb's work. As he observes in one oft-cited analysis of Australian defence policy, for instance, 'planning without such a rigorous conceptual basis only serves to legitimise ad hoc equipment acquisitions'. ${ }^{44}$ It is important to emphasise here that his utilisation of conceptual frameworks is never dogmatic or unduly prescriptive in nature. Rather, he uses conceptual frameworks more as a means for clarifying complex subject matter and for making this accessible to his readership, which routinely includes senior officials and policymakers. Such

40 See, for example, Robert S. Ross, 'The US Pivot to Asia and Implications for Australia', Centre of Gravity series, No. 5 (Canberra: Strategic and Defence Studies Centre, Mar. 2013).

41 Brad Glosserman, 'The Australian Canary', PacNet, No. 67 (21 Nov. 2011).

42 See, for example, Bjorn Elias Mikalsen Gronning, 'Japan's Shifting Military Priorities: Counterbalancing China's Rise', Asian Security, Vol. 10, No. 1 (2014), pp. 1-21.

43 Carl Thayer, 'The Philippines and Vietnam Forge a Strategic Partnership', The Diplomat, 10 Mar. 2015.

44 Paul Dibb, 'Is Strategic Geography Relevant to Australia's Current Defence Policy', Australian Journal of International Affairs, Vol. 60, No. 2 (June 2006), p. 255. 
conceptual clarity and consistency is all the more important when dealing with such an ambiguous and potentially confusing term as the balance of power.

A second defining feature of Dibb's work that is of relevance to analysing the contemporary Asian balance is his reliance upon the highest quality sources. For this reason, a close reading of Dibb's footnotes is always rewarding in its own right. His Adelphi Paper, for instance, makes regular reference to other classic works of the day, including Henry Kissinger's magisterial work Diplomacy and Paul Kennedy's Rise and Fall of the Great Powers. Dibb combines this with an iron discipline when it comes to keeping up with leading media sources. He religiously reads all of the key Australian newspapers on a daily basis and for years he has been an avid consumer of such prominent international publications as the Economist, the New York Times and the Wall Street Journal. In an increasingly crowded environment where the proliferation of blogs and various forms of social media have resulted in an overabundance of sources of information, Dibb's judgement in selecting what to read and his discipline in reading it are characteristics that will each serve contemporary analysts of the Asian balance particularly well.

Finally, Dibb's experiences both as a leading scholar and as one of Australia's most significant policy practitioners have undoubtedly combined to benefit his work on the Asian balance and to enhance the benefit of this work to these so-called 'two worlds' - the policy world and the academic world. ${ }^{45}$ While moving between these various worlds is relatively common practice in the United States - with the likes of Kissinger, Joseph Nye, Aaron Friedberg, Victor Cha and Thomas Christensen being particularly notable examples - it has been far less routine in Australia. As Dibb's intellectual home - the Strategic and Defence Studies Centre (SDSC) at The Australian National University (ANU) - celebrates its 50th anniversary in 2016, and as we honour his work in this volume, there may be no better time to rectify this situation. Perhaps the Australian Department of Defence and ANU could establish a new 'Dibb fellowship' which allows particularly gifted practitioners to spend a period of time undertaking high-quality, policy-relevant research at the SDSC.

45 For further reading see Christopher Hill \& Pamela Beshoff, Two Worlds of International Relations: Academics, Practitioners and the Trade in Ideas (London: Routledge, 1994). 
This text is taken from Geography, Power, Strategy and Defence Policy: Essays in Honour of Paul Dibb, edited by Desmond Ball and Sheryn Lee, published 2016 by ANU Press, The Australian National University,

Canberra, Australia. 